[15] Lima, A. M. F., Soldi, V., Borsali, R. (2009). Dynamic light scattering and viscosimetry of aqueous solutions of pectin, sodium alginate and their mixtures: effects of added salt, concentration, counterions, temperature and chelating agent. Journal of the Brazilian Chemical Society, 20 (9), 1705-1714. doi: 10.1590/ s0103-50532009000900020

[16] Tang, X., Alavi, S., Herald, T. J. (2008). Effects of plasticizers on the structure and properties of starch-clay nanocomposite films. Carbohydrate Polymers, 74 (3), 552-558. doi: 10.1016/j.carbpol.2008.04.022

[17] Atares, L., Bonilla, J., Chiralt, A. (2010). Characterization of sodium caseinate-based edible films incorporated with cinnamon or ginger essential oils. Journal of Food Engineering, 100 (4), 678-687. doi: 10.1016/j.jfoodeng.2010.05.018

[18] Oms-Oliu, G., Soliva-Fortuny, R., Martin-Belloso, O. (2008). Using polysaccharide-based edible coatings to enhance quality and antioxidant properties of fresh-cut melon. LWT - Food Science and Technology, 41 (10), 1862-1870. doi: 10.1016/j.lwt.2008.01.007

[19] Chen, J. L., Zhao, Y. (2012). Effect of Molecular Weight, Acid, and Plasticizer on the Physicochemical and Antibacterial Properties of $\beta$-Chitosan Based Films. Journal of Food Science, 77 (5), 127-136. doi: $10.1111 / \mathrm{j} .1750-3841.2012 .02686 . \mathrm{x}$

[20] Khan, M. I., Adrees, M. N., Tariq, M. R., Sohaib, M. (2013). Application of edible coating for improving meat quality. Pakistan Journal of Food Sciences, 23, 71-79.

[21] Evtushenko, M. V., Bredihina, O. V. (2013). Hranenie morozhenoi produkcii iz obektov vodnyh biologicheskih resursov s ispol'zovaniem plenochnyh modificirovannyh pokrytii. Rybnoe hoziaistvo, 3, 103-104.

[22] Pestina, A. A. (2011). Perspektivi vikoristannia sistem na osnovi al'gintu natriiu ta pektinu v tekhnologii kharchovih produktiv. Nizkotemperaturni ta kharchovi tehnologii u XXI stolitti, 255-257.

[23] Kambulova, Yu. V., Sokolovska, I. O. (2014). Doslidzhennya reologichnykh vlastyvostei rozchyniv pektyniv, alginatu natriyu ta yikh kompleksiv. Kharchova nauka i tekhnologiya, 26, 68-73.

[24] Dhanapal, A., Sasikala, P., Rajamani, L., Kavitha, V., Yazhini, G., Banu, M. S. (2012). Edible films of Polysaccharides. Food science and Quality Management, 13, 57-60.

\title{
STUDY OF THE PERMEABILITY DEGREE OF THE ALGINATE-CALCIUM TUNIC OF CAPSULES UNDER CONDITIONS OF THE USE OF MIXED IONOTROPIC THERMOTROPIC GELATION
}

\author{
Olga Neklesa \\ Department of technology of bread, confectionery, pasta and food concentrates \\ Kharkiv State University of Food Technology and Trade \\ 333 Klochkivska str., Kharkiv, Ukraine, 61051 \\ olgapyvovarova52@ukr.net
}

\begin{abstract}
Today scientific base of technologies of capsulated products by methods of ionotropic structuring allows to create a new segment of food industry of the Ukrainian food market. Implementation of such innovations creates preconditions for developing principles of food raw materials processing, constructing the new equipment and successful competition at the world food market.

The article studies the influence of agar and low-etherified pectin in the composition of capsules, based on gel $\mathrm{Alg}_{2} \mathrm{Ca}$ on the mass-transfer of substances at the expanse of thermotropic gelation. Obtained results testify to the possibility to create systems with different permeability for high- and low-molecular substances on this base. Studied systems are characterized with different speeds of releasing active substances that may be used for providing their prolonged effect on the human organism. Modification of alginate-calcium tunics of capsules with the internal fatty raw material content by using the method of mixed gelation allows to correct structural-mechanical and, as a result, organoleptic and quality parameters of capsulated
\end{abstract}


products. Determination of the active acidity influence on texture parameters allows to correct a speed and regulations of releasing internal contents in zones of the gastrointestinal tract at homeostasis that allows to control physiological ability of innovative products.

Keywords: alginate-calcium tunic, permeability of capsule tunic, ionotropic-thermotropic gelation, modification of alginate gels, acidity of external environment.

\section{Introduction}

Today representatives of food industry face global tasks for creating technologies of ecological raw materials and their processing. It is realized by elaborating an innovative and investment production strategy, implementation of principles of the most effective use of raw materials, rational use of energy, equipment, production lines and working force. Such technologies include ones of capsulation of oil-fat raw materials and systems in edible tunics, based on polysaccharides. Capsulation processes are based on ones of formation of a new phase - tunic, mainly of solutions or melts of polymers (film-creators) under certain conditions on particles of substances $[1,2]$. The tunic separates them from each other and from the external environment. The internal content of capsules is released as a result of destructing the tunic as a result of crushing, dissolution, melting, heating or at the expanse of gradual release of substances in the environment by diffusion through the permeable tunic of a capsule with a speed that depends on its thickness and porosity [3, 4]. Peculiarities of the chemical construction of salts of alginic acid provide stability of capsulated products on their base under influence of gastric juice and program release of the content of capsules as a result of biodegradation in the intestine [5].

Based on the conducted complex of theoretical, analytical and practical studies, the technology of lipids of capsulated food raw materials (LFCRM) with the wide line of type-series and assortment was scientifically grounded, elaborated and implemented in production [6-8]. LFCRM technology is based on principles of ionotropic gelation at the expanse of realizing chemical potentials of sodium alginate $(\mathrm{AlgNa})$ and $\mathrm{Ca}^{2+}$ and interconnection of components, used at getting capsulated systems. It is provided, that ways of using LFCRM in food industry will be determined by their functional-technological and physiological properties. It, in first turn, is influenced by the recipe composition of the alginate-calcium tunic and internal fatty content. It must be understood that structural-mechanical, texture, physical-chemical characteristics, ability to react or restrain external technological factors will determine organoleptic and consumption parameters of LFCRM and food products with their use [9]. It was established, that modification of properties of alginate-calcium tunics of LFCRM is important at using gel-creators, different by origin and principles of structuring [10]. Among them, polysaccharides (agar, pectins, starches) and protein substances (gelatin) are traditionally used. At that the main scientific and practical tasks are to study structural-mechanical properties of structured systems that determine organoleptic parameters and thermodynamic compatibility of recipe components in capsulated products. At the same time they determine the texture homogeneity of a product, homeostasis duration, parameters of technological process and terms of its storage. It is also necessary to take into account $\mathrm{pH}$ of main raw materials and environment, able to influence the system's stability and conditions of storing ready products [11, 12].

The choice of a structure-creator for modifying alginate-calcium tunics of capsulated products may be based on two principles. At first, it must not change its functional properties according to results of changing the main and auxiliary raw material under different conditions. This principle is used only if a structure-creator is chemically indifferent, colloid-stable and doesn't react on the main raw material. From the other point of view, a structure-creator involves properties of other recipe components in the process of structuring up to the synergetic interaction. In such a way it provides necessary structural-mechanical, organoleptic parameters and stability at storage. Another way for creating capsulated products, based on mixtures of polysaccharides is more promising, but needs the detail choice of structure-creators with correspondent properties. Creation of a complex modified gel is possible at the expanse of combining two or more hydrocolloids, able to 
demonstrate the effect of synergism. Synergetic combinations of neutral or acid polysaccharides or combination of acid polysaccharides and proteins are practically used.

The author presents the working hypothesis that the synchronous use of several thermotropic and/or ionotropic gel-creators with the water solution $\mathrm{CaCl}_{2}$ in a common dissolvent at drop extruding in the water solution AlgNa allows to realize chemical potentials of these substances. At observing declared technological parameters, it is possible to get capsulated products with properties of used gel-creators. In this case the measure of thermotropic and ionotropic properties of LFCRM will be determined by the ratio of participants of the process.

For studying the possibility of interaction of gel-creator in the composition of the mixed gel, there were studied the systems «AlgNa - agar - $\mathrm{Ca}^{2+}$ - water» and «AlgNa - low-etherified pectin- $\mathrm{Ca}^{2+}$ - water». There was assumed that nets of ionotropic gel $\mathrm{Alg}_{2} \mathrm{Ca}$, agar and low-etherified pectin create frame structures of products and exist in it without chemical interaction. In whole properties of these gels are manifested as a sum of properties of gels, created by two gel-creators with predominance of parameters of a dominating component. Taking into account the ability of AlgNa and low-etherified pectin to interact with ions of bivalent metals, at adding $\mathrm{Ca}^{2+}$ to the system, probably there will take place the competition for the possibility to enter the interaction with $\mathrm{Ca}^{2+}$ and to create the complex « $\mathrm{Alg}_{2} \mathrm{Ca} »$ and $« \mathrm{Ca}^{2+}-$ low-etherified pectin". But based on the chemical potential of substances, $\mathrm{AlgNa}$ is characterized with much more expressed interaction with $\mathrm{Ca}^{2+}$, than pectin. As a result of it, the dominating amount of $\mathrm{Ca}^{2+}$ creates chelate compounds just with $\mathrm{AlgNa}$. So, the mixed gel mostly demonstrates properties of $\mathrm{Alg}_{2} \mathrm{Ca}$ gel, especially as for thermal stability. In the system «Alg $\mathrm{Na}-$ agar $-\mathrm{Ca}^{2+}-$ water» only $\mathrm{AlgNa}$ interacts with $\mathrm{Ca}^{2+}$, because the sulphitated polysaccharide has no expressed ability for complex-creation at $\mathrm{Ca}^{2+}$.

It may be foreseen, that at the expanse of different mechanisms of gel-creating, the permeability of aginic-pectin and alginic-agar tunics will be different that has the essential physiological value. In the experimental sample it concerns, first of all, penetration of GIT lipases to the fatty content of capsules that will determine the speed of their digestion and assimilation. At the same time this experiment will indirectly testify the density of nets of the gel, because density is not an objective parameter under such conditions.

So, the study of ways for modifying properties of the alginate-calcium tunic of capsulated products is an urgent task, because it allows to widen the assortment of substances that may be encapsulated essentially, to facilitate the technological process of manufacturing capsulated products and to get ready products as new forms, ready to consumption. Thus, the aim of the study is to establish the influence of modifying substances as hydrocolloids of different origins on the physical-chemical properties of alginate-calcium tunics of capsules and to investigate the behavior of capsulated systems in mediums with different acidity values. Such modification of tunics of capsules allows essentially influence organoleptic parameters and physiological value of capsulated products, including enzymes effect at digestion.

\section{Materials and Methods}

Within the study of the permeability degree of alginate-calcium tunics in LFCRM composition and $\mathrm{pH}$ medium influence on their properties, we chose gel systems «AlgNa - agar $-\mathrm{Ca}^{2+}-$ water» and «AlgNa - low-etherified pectin $-\mathrm{Ca}^{2+}$ - water» as a subject of the study. There were also studied fatty food capsulated semi-products, based on sunflower and olive oil (Fig. 1).

Determination of the model of elasticity and firmness of mixed gels based on $\mathrm{Alg}_{2} \mathrm{Ca}$ and agar or low-etherified pectin was realized on the modified scales of Cargin-Sokolova by studying contraction deformation of structured systems under the effect of a chisel at the stable tension. The obtained values of rheological characteristics were processed in the program of automated processing of experimental researches.

Tunics' permeability was studied on regulations of the diffusion intensity of white sugar $(\mathrm{C}=5,0 \%)$ from the body of alginic-pectin or alginic-agar gel [8].

For studying the active acidity influence, the experimental samples were placed in mediums with different $\mathrm{pH}$ values: 2,0 (acid medium), 4,0-6,0 (neutral medium) and 8,0 (alkaline medium). 
The experimental systems were kept up to establishing the constant module of elasticity of the structured scheme.

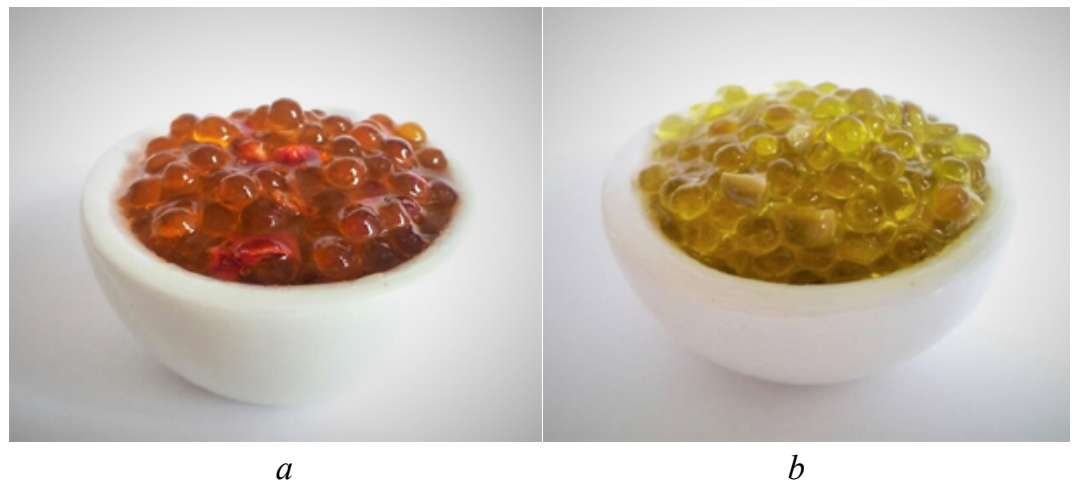

Fig. 1. Photo look of research objects: $a$ - semi-product of capsulated sunflower oil with carotenoids; $b$ - semi-product of capsulated olive oil

\section{Results}

It was analytically established, that the high physiological value of pectins as soluble food fibers influences their ability to gelation under conditions of adding sugars or decreasing $\mathrm{pH}$ that determines their wide use in food industry [13]. Under conditions of their use in LFCRM technology, there was taken into account the functional ability of low-etherified pectins, used before interaction with $\mathrm{Ca}^{2+}$. It conceptually gives a possibility of pectins' participation in the common polymerization of the matrix $\mathrm{Alg}_{2} \mathrm{Ca}$. It was additionally taken into account, that calcium pectates are characterized by the expressed acid stability. It allows to foresee that at penetrating LFCRM in the alginic-pectin tunic in the gastric medium with $\mathrm{pH}$ values $1,5 \ldots 3,5$, the integrity of a capsule is saved on the background of the effect of enzymes of pepsin and gastrin. Under this condition, the mass exchange from the stomach through the tunic in the middle of a capsule and reverse one will condition properties of the alginate-pectin tunic.

As opposite to agar, that forms the "physical gel", low-etherified pectin forms a polymer at the expanse of chemical junctions, so for AlgNa the essence of this gelation relates to the "chemical polymerization", with the increase of the mean molecular mass. Such gels are irreversible [6].

For estimating permeable properties of alginic-pectin or alginic-agar tunics, there was conducted the intermediate experiment on model systems. Under conditions of the weight concentration $\mathrm{A} \operatorname{lgNa} \mathrm{C}=1,4 \%$ in the system, its concentration changed by 0,$2 ; 0,4 ; 0,6 \%$ of low-etherified pectin or agar. At such approach at the total side mass concentration of the gel-creator $A \operatorname{lgNa} C=1,4 \%$, its structure changes probably proportionally to the partial contribution of components of participants of combined gelation.

Fig. 2 presents profiles of diffusion ("output") of white sugar from the matrix of alginic-pectin gel in the water medium at rest (Fig. 2, a) and under conditions of using forced diffusion at the expanse of fluctuations 2 fluct/s (Fig. 2, b).

Fig. 3 presents profiles of diffusion ("output") of white sugar from the matrix of the alginic-agar gel in the water medium at rest.

The analysis of the presented graphic regulations allows to detect that the gel $\mathrm{Alg}_{2} \mathrm{Ca}$ is the least permeable for low-molecular substances. At passive keeping and forced exciting fluctuations it is shortened. But it is essentially permeable at diffusion with the gel medium. Modification of gels by the gradual increase of the mass share of agar ("physical gel") and low-etherified pectin ("chemical gel") probably leads to a certain "loosening" of the gel structure. It is testified by the essential growth of the diffusion coefficient of alginic-pectin gel and intensification of the process.

These results testify to the possibility of gels modification to the side of density growth for agar and pectin gels at adding AlgNa, to its loosening at adding agars or low-etherified pectins in the structure of the aginic-calcium structure.

The peculiarity of LFCRM production technology is in supplying a semi-product with a certain consistence that depends on many factors. The change of the consistence of the given 
semi-product, in first turn, depends on the content of acid, kitchen salt and fatty raw material (internal fatty content).
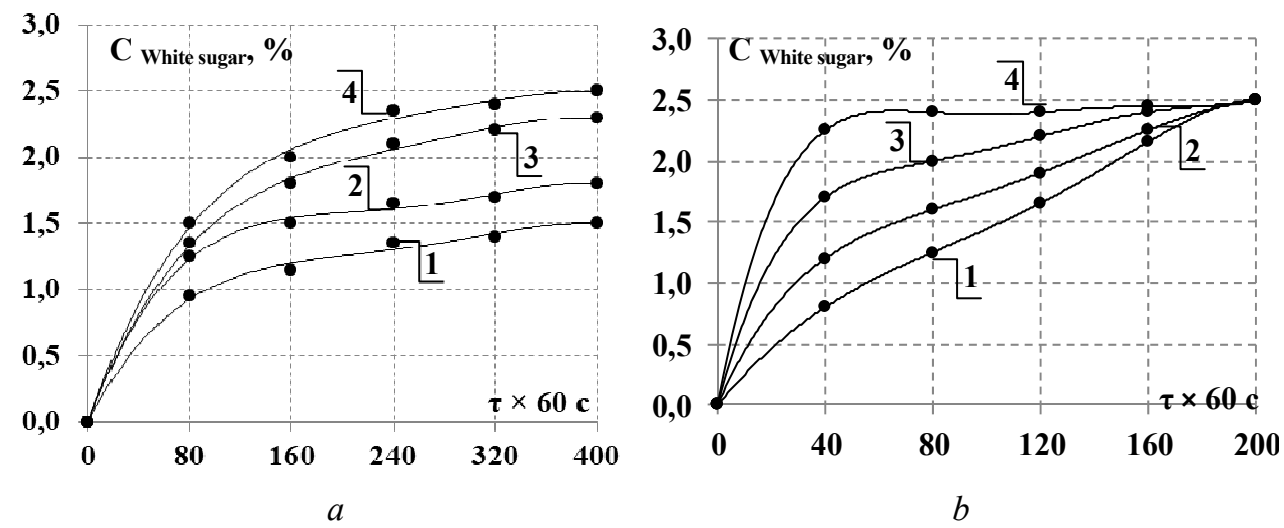

Fig. 2. Profiles of diffusion ("output") of white sugar from the alginic-pectin gel in the water medium: $a$-without fluctuations; $b$ - under conditions of using forced diffusion at the expanse of

fluctuations 2 fluct/s At following concentrations of recipe components: 1 - AlgNa 1,4 \%;

$2-\mathrm{A} \operatorname{lgNa} 1,2 \%$ and low-etherified pectin $0,2 \% ; 3-\mathrm{AlgNa} 1,0 \%$ and low-etherified pectin $0,4 \% ; 4-\mathrm{AlgNa} 0,8 \%$ and low-etherified pectin $0,6 \%$ respectively.

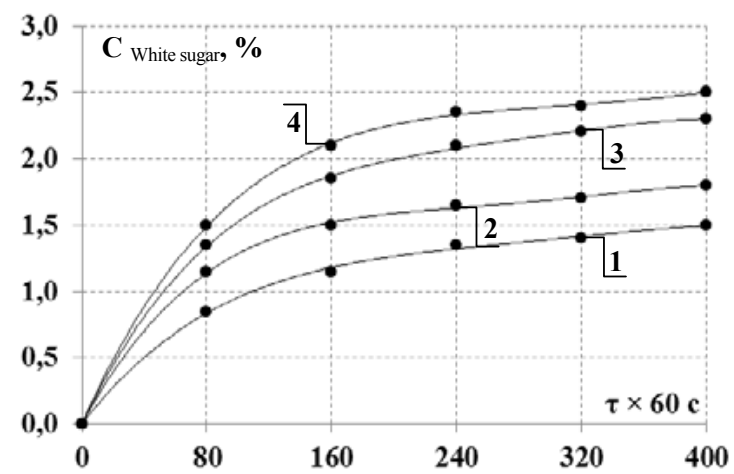

Fig. 3. Profiles of diffusion ("output") of white sugar in the water medium without forced fluctuations at the following concentrations of the recipe components: 1 - AlgNa 1,4 \%;

$2-\mathrm{A} \operatorname{lgNa} 1,2 \%$ and agar $0,2 \% ; 3-\mathrm{AlgNa} 1,0 \%$ and agar $0,4 \% ; 4-\mathrm{AlgNa} 0,8 \%$ and agar $0,6 \%$

It was established that the acidity of the external medium at $\mathrm{pH} 2,0 \ldots 4,0$ results in increasing viscosity of the mixture. It is explained by salting ability of $\mathrm{AlgNa}$. So, it is rational to use acid after creating the capsulated semi-product in the technological system. There was studied the influence of $\mathrm{pH}$ of the medium on structural-mechanical properties of mixed gels, based on $\mathrm{Alg}_{2} \mathrm{Ca}$ and agar. As experimental samples, there were chosen the mixtures, where the agar content is $0,4 \%$ and $0,8 \%$, because at this diapasons of agar concentrations the structured schemes were characterized by the given organoleptic parameters. The obtained dependencies of the elasticity module of mixed gels on $\mathrm{pH}$ of the medium are presented on Fig. 4.

The presented dependencies are dynamic. It is obvious, that at $\mathrm{pH} 2,0$ the elasticity module reaches the highest values. It testifies to compression of the gel. At $\mathrm{pH} 8,0$ the opposite situation is observed, gels partially lose firm properties and the changes of their outlook takes place. Fig. 5 presents the change of the outlook of the alginic-agar gels from $\mathrm{pH}$ values of the medium.

Thus, as a result of the conducted studies, it was established, that the essential amount of acid $(\mathrm{pH} 2,0)$ in the mixed gel results in creation of the very solid gel. By measuring size characteristics, it was established, that the gel system decreases in 2,12 times that is connected, in first turn, with compression of the net of the gel, conditioned by salting of AlgNa. At pH 8,0, maximally approximated to $\mathrm{pH}$ of kitchen salt - the reverse dependence is observed. Gels increase in 
1,17 times, but they partially lose the integrity of the gel structure and become softer comparing with the control. It was established, the rational $\mathrm{pH}$ value of the medium of structured schemes, based on mixed gels is $\mathrm{pH} 5,0$.

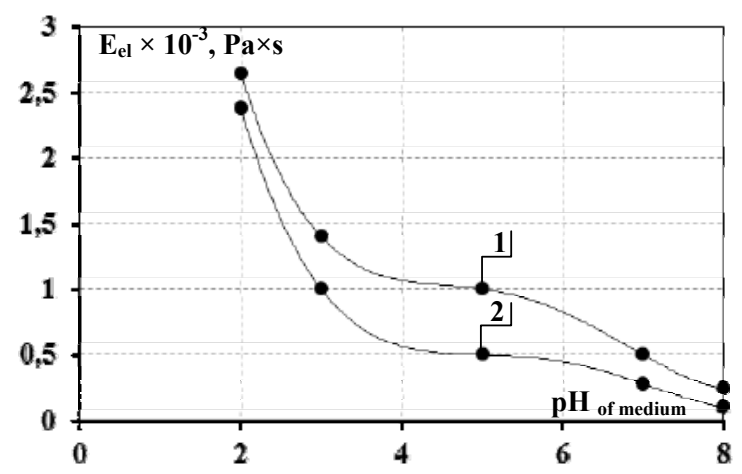

Fig. 4. The dependence of elasticity module of alginic-agar gels on $\mathrm{pH}$ of the medium at the concentrations $\mathrm{AlgNa} 2,0 \%, \mathrm{CaCl}_{2} 0,4 \%$ and agar, \%: $1-0,4 ; 2-0,8$ respectively.

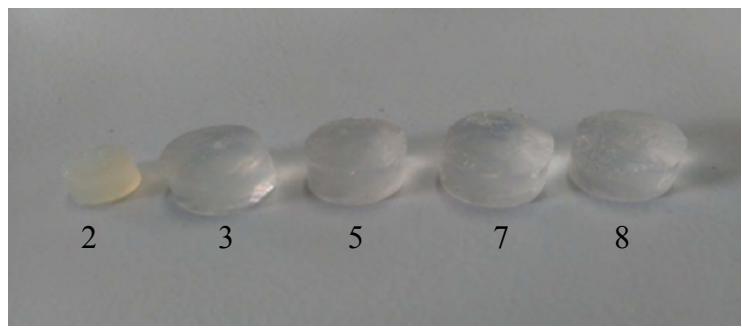

Fig. 5. Photo of alginic-agar gels on the $\mathrm{pH}$ values of the medium at the concentrations $\mathrm{AlgNa} 2,0 \%$, $\mathrm{CaCl}_{2} 0,4 \%$ and agar $0,8 \%$ (from the left to the right $\mathrm{pH} 2,0 \ldots 8,0$ )

\section{Conclusions}

One of today intensively developed directions is creation of capsulated food products. Scientific-technological principles of capsulation of hydrophobic food and technological schemes are insufficiently grounded in the world practice. LFRM capsulation is a component of the scientific direction of getting the structural schemes, which share in the food balance structure in the world grows intensively. The use of food ionotropic polysaccharides, including alginates is promising in the technology of capsulated products with the internal fatty content. It was proved that the use of water soluble salts of alginate as a structure-creator allows to give to structural food products the necessary spheric form, high taste indices, new properties, to provide their stability against the technological influence. Technological properties of LFCRM depend on many parameters of the technological process. It was proved that modification of alginate-calcium tunic of a capsule with the internal fatty acid content is possible by "solving" the gel by other polysaccharides, able to the synergetic effect with $\mathrm{Alg}_{2} \mathrm{Ca}$. Adding agar with getting the "physically mixed gel" or pectin with getting the "chemically mixed gel" allows to correct structural-mechanical properties of the alginate-calcium tunic of a capsule to the side of increase or decrease of density characteristics. There was studied the mechanism of the mixed gelation of the system «AlgNa - agar $-\mathrm{Ca}^{2+}$ - water», and «AlgNa - low-etherified pectin $-\mathrm{Ca}^{2+}$ - water». There were determined the regularities of the influence of recipe components on LFCRM properties. It was revealed,

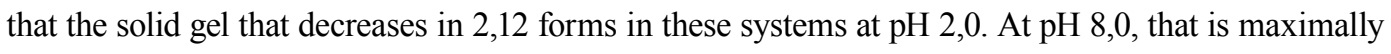
approximated to $\mathrm{pH}$ of kitchen salt, there is observed the reverse dependence of the gel - it increases in 1,17 times, but partially loses the gel structure integrity and becomes softer.

The advantage of this technology is a possibility to transform a raw material in the state, intact to the environment. Such approach covers the wide spectrum of products - oil-fat, fruit-vegetable, fruit, milk raw materials and products of their processing that have the rather limited use in food technology. The offered technology allows to widen the spectrum of using these products, to enrich their composition by vitamins, mineral substances and other. In its turn, it allows to offer food products with the balanced chemical composition and target physiological value to the consumption market. 


\section{References}

[1] Voskanyan, O. S., Paronyan, V. Kh., Valitov, Z. O. (2013). Voprosy mikro-kapsulirovaniya pishhevykh emul'sionnykh produktov. Khranenie i pererabotka sel'khozsyr'ya, 8, 114-116.

[2] Tekhnologii i produkty zdorovogo pitaniya. Funktsional'nye pishhevye produkty. Obzornaya informatsiya (2010). Moscow: MGUPP, 204.

[3] Polishhuk, T. S., Tkachuk, I. O., Skripnik, Yu. V. (2011). Geleobrazovateli v farmatsii. Karbopol. Al'ginaty. Available at: http://www.rusnauka.com/NPM_2006/Chimia/4_polischuk\%20t.s..doc.htm

[4] Braccini, I., Grasso, R. P., Perez, S. (1999). Conformational and configurational features of acidic polysaccharides and their interactions with calcium ions: a molecular modeling investigation. Carbohydrate Research, 317 (1-4), 119-130. doi: 10.1016/s0008-6215(99)00062-2

[5] Pivovarov, P. P., Neklesa, O. P., Nagorniy, O. Yu. (2013). Innovatsionnye tekhnologii proizvodstva kapsulirovannykh produktov. Produkty i ingredient, 3 (100), 24-269.

[6] Neklesa, O., Yarantseva, Y., Pyvovarov, Y., Grinchenko, O. (2017). Study of constructive provision of the capsule formation process of the "Oil and fat raw materials - ionotropic shell-maker" system. EUREKA: Physics and Engineering, 6, 42-47. doi: 10.21303/2461-4262.2017.00508

[7] Korotaeva, E. A. (2014). Vliyanie komponentnogo sostava na svoystva dvukhsloynoy priemnoy sredy $\mathrm{v}$ tekhnologii koaksial'noy vertikal'noy ekstruzii. Kharchova nauka i tekhnologiya, 2 (27), 45-48.

[8] Korotaeva, E. O., Neklesa, O. P., Grinchenko, O. O., Pivovarov, P. P. (2015). The study of functional-technological properties of encapsulated vegetable oils. Eastern-European Journal of Enterprise Technologies, 6 (10 (77)), 16-23. doi: 10.15587/1729-4061.2015.56198

[9] Pyvovarov, Ye. P., Nahornyi, O. Yu., Pyvovarov, P. P. (2010). Doslidzhennia fizyko-khimichnykh zmin napovnenykh heliv na osnovi natriiu alhinatu (ALgNa) ta natriikarboksymetyltseliulozy (NaKMTs). Prohresyvni tekhnika ta tekhnolohii kharchovykh vyrobnytstv restorannoho hospodarstva i torhivli, 1 (11), 20-23.

[10] Bechtel, S. E., Forest, M. G., Wang, Q., Zhou, H. (1999). Free surface viscoelastic and liquid crystalline polymer fibers and jets. Advances in the Flow and Rheology of Non-Newtonian Fluids. New York: Elsevier, 1069-1116. doi: 10.1016/s0169-3107(99)80014-8

[11] Tsuchida, E., Takeoka, S. (1994). Interpolymer Complexes and their Ion-Conduction. Macromolecular Complexes in Chemistry and Biology. Berlin: Springer, 183-213.

[12] Nahornyi, O. Yu., Pyvovarov, Ye. P. (2010). Zakonomirnosti formuvannia masy obolonok kapsul, oderzhanykh shliakhom ionotropnoho heleutvorennia. Naukovi pratsi Odeskoi natsionalnoi akademii kharchovykh tekhnolohii, 38, 166-173.

[13] Plotnikova, R. V., Hrynchenko, N. H., Moroz, O. V., Pyvovarov, Ye. P. (2013). Pat. No. 102341 UA. Hranulovanyi produkt ta sposib yoho oderzhannia. MPK A23C 9/00, A23P 1/12, A23P 1/02, A23C 9/14, A23C 7/00. No. a201207329; declareted: 15.06.2012; published: 22.05.13, Bul. No. 12, 3. 